中村芳樹 [東京工業大学大学院総合理工学研究科 人間環境システム専攻 助教授・エ博] 国内の住宅の光環境は余り質の高いものではないというぼんやり とした認識はあるが, 光環境の改善を進めるにしても, 実際にどの よjな実態であるかを知ることは重要である。本論文はこのような ニーズに答えた全国規模の調查をまとめたもので，その価値が高い といえるだろう。結論にある, 一室一灯が大多数である現状や,もっ と明るくしたいという希望がいまだに多いこと, 若年層の昼間の照 明点灯率が高いという報告には, 特に注意すべきである。通常の住 宅では，実際には照明設計がほとんど行われておらず，適所適光と いう状況に程遠いという現状が，このような結果をもたらしている のだろう。省エネルギーの実現という観点からも, 光環境の質を高 めようという世論を作り出す活動が必要であると感じた。
佐藤仁人 [京都府立大学人間環境学部環境デザイン学科 教授・工博] 10 年前の調查と比べて一室一灯照明が変わっていないとのこと である。照明は住宅問題そのものであると考えさせられた。第二次 大戦後の住宅不足解消に, コンパクトな住宅が数多く供給され, 部 屋は 3 6 嘼があたりまえの広さであった。これに天井中央から一灯 の蛍光灯がぶら下がっていれば部屋は隅々まで十分明るい。多灯に する必要などなく，この慣性力が今でも強く働いている。その後, 日本は高度経済成長を遂げ，物質的には豊かになった。住空間の豊 かさの基本が広さであることを考えると，今後少しは広くなるであ ろう。しかし, この調査の結果は, 10 年前と住宅のグレードが大き くは改善されていないことを示している。近年，一室多灯照明が議 論され始めたが，住宅が広くなれば自ずと多灯照明になるのであろ う。ともあれ，この調查により色々な連想や考察が膨らむのである からきわめて貴重である。継続的な調査を期待する。
井川憲男 [大阪市立大学大学院生活科学研究科 教授・工博] 都市のヒートアイランド現象の低減に向け，建材表面における太 陽放射の反射・吸収特性に関する基礎研究は非常に重要である。本 報告では建材表面での太陽放射の反射・吸収に着目し, 多くの建材 について実測で得た基礎デー夕を整理し, 建材の色と吸収特性との 関係を定量的に表すことを目的としている。しかし，本研究の核と 考えられる太陽放射の影響を受けた建材の温度測定では，その表面 温度と最も因果関係が深い外乱と考之られる日射量, 外気温度, 風 速などについての測定がなく, ある特定されない外乱条件下での材 料種別ごとの明度指数と表面温度の関係が示されている。示された 建材の温度特性は天候条件により異なる性格のものであり, 外乱と の関係が定量化されるには至っていない。そのため, 太陽放射を受 けた建材の明度指数が大きいと表面温度が低いという従来の定性的 概念を証明するに留まっている。定量化に向けた, 今後の研究の進 展に期待したい。
三井所清典 [(株)アルセッド建築研究所 代表取締役 $]$ 建築物が太陽エネルギーの吸収・反射を繰返すうちに建築に蓄積 される熱の放出が周辺の大気を加熱するなど都市の温暖化に影響を 及ぼしているとすると建材の表面温度を下げる研究は環境緩和に寄 与することになる。

この実験研究は建築の外装材としてよく使用されるコンクリー ト, アスファルト, 石材, 磁器タイル及びレンガについて表面の粗 さと色と太陽日射の吸収特性を調べ, JIS Z 8730 で定義される明度 指数 L*でそれら建材の表面温度を定量化する可能性を導き出して いる。すなわち建材の色の明度を変えることで太陽エネルギーの吸 収による表面温度を計画的に操作することが可能になる。しかもそ の指数は可視領域の波長をもとにしているからこれまでの反射率測 定の全波長領域の計測と比べ，比較的容易に実用化する可能性が高 い。技術には正確さを求精緻をきわめる方法と一定の有効性のも とで広く普及をはかる方法があるがこの研究は後者に近く, 今後の 発展が期待される。

\title{
北海道における住宅用ガラス被覆付設空間に関する調查 －濃霧発生地域におけるサンルーム付き住宅の有効性について一
}

佐藤彰治, 絵内正道 211

小玉祐一郎 [神戸芸術工科大学芸術工学部環境デザイン学科 教授・工博]

多用途の生活装置として付設されるサンルームは, パッシブソー ラ一暖房の集熱部位として，冬の暖房を補助する一手法と位置づけ られる。しかし, 地域の気候特性や居住者の使い方にマッチしない 場合には，逆効果となる場合もありうる。ここでは，夏に濃霧の発 生しやすい地域での通年の活用法を中心として, 道東地方のサン ルームの実態調查の結果が報告されている。通年のガラスの集熱効 果 (暖房効果) や湿度調整効果が評価される反面, 結露やオーバー ヒートなどのマイナスの評価も少なくない。サンルームの外部開口 部の開閉, 居間側開口部の開閉の仕方の不適切さがマイナス評価の 原因となる場合が多いことも明らかにされた。断熱化・気密化が進 んだ北欧では北向きのサンルームがよいとする極論があったりする が, 地域特性やライフスタイルに応じて, 多用なサンルームのデザ インが可能であり, 多用な活用法・楽しみ方があることを，この報 告は教えてくれる。
野口孝博 [北海道大学大学院工学研究科都市環境工学専攻 教授・工博 $]$

本研究は, 夏期に濃霧が発生して低温多湿の特有の気象条件を有 する北海道の東部地域において住宅付設空間としてのサンルーム, 風除室等の保有状況とその利用実態, 使用効果を検討することによ り，固有の地域条件下における住宅近傍がラス被覆空間による居住 環境改善効果を探ろうとする研究として注目される。本稿でも示さ れているが北海道で一般的に見られるがラスの玄関風除室は，出入 ク口空間における室内側の環境保護と同時に出入りに伴う種々の生 活を受け入れる中間領域的スペースとしての意味がある。本稿で着 目しているサンルームについては，同様に室内側の環境改善効果と 併せて, 同じ中間領域的スペースでもより室内側生活との結びつき がつよく，その意味では四季を通して家の中の生活をどのように改 善するかにつながる計画的研究でもある。今後はサンルームの環境 改善効果と併せて北国の屋内生活の魅力化という生活様式の視点も 加えて検討することが望まれる。新しい住宅計画理論の根拠を提供 してくれる研究として期待される。 